\title{
PENGARUH MODEL PEMBELAJARAN GENERATIF TERHADAP HASIL BELAJAR SISWA PADA MATERI POKOK HUKUM NEWTON DI SMP YAYASAN PERGURUAN BUDI AGUNG MEDAN MARELAN T.P. 2013/2014
}

\author{
Siti Aisyah Lubis dan Derlina \\ Jurusan Fisika FMIPA Universitas Negeri Medan \\ Jalan Willem Iskandar Pasar V Medan, Sumatera Utara \\ adelynaoktavia46@gmail.com
}

\begin{abstract}
ABSTRAK
Penelitian ini bertujuan untuk mengetahui pengaruh model pembelajaran generatif terhadap hasil belajar siswa pada materi pokok Hukum Newton di kelas VIII semester I SMP Yayasan Perguruan Budi Agung Medan Marelan T.P. 2013/2014. Jenis penelitian ini adalah quasi experiment. Populasi dalam penelitian adalah seluruh siswa kelas VIII Semester I SMP Yayasan Perguruan Budi Agung Medan Marelan yang terdiri dari 5 kelas. Pengambilan sampel dilakukan dengan cara cluster sampling dengan mengambil 2 kelas dari 5 kelas secara acak. Instrumen yang digunakan untuk mengetahui hasil belajar siswa adalah tes hasil belajar dalam bentuk pilihan berganda dengan jumlah 15 soal. Berdasarkan analisa data diperoleh hasil pretes dan postes kedua kelas yang berdistribusi normal dan homogen. Hasil postes diperoleh rata-rata kelas eksperimen yang menggunakan model pembelajaran generatif 70,44 dan kelas kontrol yang menggunakan model pembelajaran langsung 60,44. Hasil uji $t$ diperoleh $t_{\text {hitung }}=2,06$ dan $\mathrm{t}_{\text {tabel }}=1,84$ sehingga $\mathrm{t}_{\text {hitung }}>\mathrm{t}_{\text {tabel }}(2,06>1,84)$ maka $\mathrm{H}_{0}$ ditolak dan $\mathrm{H}_{\mathrm{a}}$ diterima, dengan demikian terdapat perbedaan akibat pengaruh model pembelajaran generatif terhadap hasil belajar siswa pada materi pokok Hukum Newton di kelas VIII semester I SMP Yayasan Perguruan Budi Agung Medan Marelan T.P. 2013/2014.
\end{abstract}

Kata kunci : Model pembelajaran generatif, hasil belajar

\section{PENDAHULUAN}

Pendidikan mempunyai peranan yang penting karena pendidikan dapat membentuk manusia yang berkualitas. Undang-Undang No.20 tahun 2003 tentang sistem Pendidikan Nasional menyatakan bahwa:

"Pendidikan adalah usaha sadar dan terencana untuk mewujudkan suasana belajar dan proses pembelajaran agar peserta didik secara aktif mengembangkan potensi dirinya untuk memiliki kekuatan spiritual keagamaan, pengendalian diri, kepribadian, kecerdasan, akhlak mulia, serta keterampilan yang diperlukan dirinya, masyarakat, bangsa dan negara".

Untuk mewujudkan tujuan pendidikan, guru memiliki peranan yang besar agar tercipta sumber daya manusia yang berkualitas salah satunya dalam bidang ilmu fisika.

Berbicara tentang peranan fisika maka tidak akan lepas dari pembelajaran fisika di sekolah dan masalah yang ada di dalamnya. Pada proses pembelajaran fisika siswa menganggap pembelajaran fisika sulit dipahami dan kurang menarik serta pembelajaran yang kurang bervariasi. Sehingga siswa kurang aktif dan hasil belajar fisika yang diperoleh belum optimal. Dalam permasalahan ini, guru sebagai 
pengajar di sekolah tentu saja tidak bisa dipersalahkan secara sepihak jika masih ada siswa yang mengalami kesulitan belajar fisika, karena pada dasarnya terdapat banyak faktor yang mempengaruhi keberhasilan siswa dalam belajar, baik dari dalam diri siswa itu sendiri, maupun faktor dari luar.

Slameto (2010:54) menyatakan faktor-faktor yang mempengaruhi belajar banyak jenisnya, tetapi dapat digolongkan menjadi 2 golongan saja, yaitu faktor intern dan faktor ekstern, tetapi setelah dijabarkan lagi faktor yang mempengaruhi seseorang dalam belajar, antara lain: (1) intelegensi, (2) faktor kesehatan, (3) perhatian, (4) minat, (5) bakat, (6) motif, (7) kematangan, (8) kesiapan belajar, (9) cara penyajian materi, (10) relasi guru dengan siswa, (11) alat pelajaran, (12) kondisi masyarakat luas. Tetapi, dari 12 poin tersebut, cara penyajian materi pada kegiatan belajar mengajar merupakan salah satu upaya untuk meningkatkan kualitas pembelajaran sekaligus menjadi penentu keberhasilan belajar siswa.

Rendahnya hasil belajar fisika ini sesuai dengan hasil wawancara dengan guru fisika kelas VIII SMP Yayasan Perguruan Budi Agung Medan Marelan. Diperoleh informasi hasil belajar fisika siswa yang pada umumnya masih rendah yaitu rata-rata 65 sedangkan Kriteria Ketuntasan Minimal (KKM) yang akan dicapai adalah 70 . Sehingga dapat dikatakan nilai rata-rata siswa tidak mencapai kriteria yang diharapkan. Hal ini disebabkan karena siswa menganggap pelajaran fisika merupakan pelajaran yang sulit, membosankan, banyak menghafal rumus serta jauh dari kehidupan sehari-hari siswa. Di sisi lain guru kurang menggunakan model pembelajaran yang bervariasi, cenderung terpaku pada satu model yaitu model pembelajaran langsung (Direct Instruction). Hal ini mengakibatkan pembelajaran terkesan monoton dan membosankan serta menjadikan siswa pasif saat proses pembelajaran berlangsung.
Berdasarkan permasalahan di atas,diperlukan model pembelajaran yang dapat mengatasi masalah ini yakni model pembelajaran generatif yang berlandaskan teori konstruktivisme.

Pembelajaran Generatif (PG) merupakan terjemahan dari Generative Learning (GL). Menurut Osborno dan Wittrock yang dikutip oleh Holil (2008 :4) bahwa pembelajaran generatif merupakan suatu model pembelajaran yang menekankan pada pengintegrasian secara aktif pengetahuan baru dengan menggunakan pengetahuan yang sudah dimiliki siswa sebelumnya. Pengetahuan baru itu akan diuji dengan cara menggunakannya dalam menjawab persoalan maupun gejala yang terkait. Jika pengetahuan baru itu berhasil menjawab permasalahan yang dihadapi, maka pengetahuan baru itu akan disimpan dalam memori jangka panjang.

Ada beberapa hal yang mendapat perhatian khusus dari model pembelajaran genaratif yaitu, pengetahuan awal, motivasi, perhatian, dan pengalaman belajar. Wittrock yang dikutip oleh Sa'adah (2009:5) menyimpulkan bahwa pembelajaran melalui proses generatif akan berhasil dengan memperhatikan keempat faktor tersebut. Keempat hal yang menjadi perhatian khusus dalam model pembelajaran generatif diharapkan dapat mendorong siswa untuk ikut berpartisipasi aktif dalam kegiatan pembelajaran fisika. Sehingga diharapkan dapat meningkatkan ketercapaian hasil belajar siswa yang selama ini masih tergolong rendah.

Berdasarkan uraian di atas maka peneliti mencoba melakukan penelitian dengan tujuan untuk mengetahui pengaruh model pembelajaran generatif terhadap hasil belajar siswa pada materi pokok Hukum Newton di kelas VIII semester I SMP Yayasan Perguruan Budi Agung Medan Marelan T.P. 2013/2014.

\section{METODE PENELITIAN}

Penelitian ini telah dilakukan di SMP Yayasan Perguruan Budi Agung Medan 
Marelan kelas VIII semester I pada tanggal 23 Agustus 2013 sampai dengan 21 September 2013 yang berjumlah 2 kelas dengan menggunakan teknik cluster random sampling. Satu kelas dijadikan sebagai kelas eksperimen dengan model pembelajaran generatif dan satu kelas lagi dijadikan sebagai kelas kontrol dengan model pembelajaran langsung. Desain penelitian Two Group Pretest-Posttest seperti ditunjukkan pada Tabel 1.

Tabel 1. Two Group Pretest-Postest Design (Arikunto, 2010 : 125)

\begin{tabular}{|l|c|c|c|}
\hline Kelas & Pretest & Perlakuan & Postes \\
\hline Eksp & $\mathrm{X}_{1}$ & $\mathrm{G}$ & $\mathrm{X}_{2}$ \\
Kont & $\mathrm{X}_{1}$ & $\mathrm{~K}$ & $\mathrm{X}_{2}$ \\
\hline
\end{tabular}

Keterangan :

$\mathrm{X}_{1}=$ Pemberian pretes

$\mathrm{X}_{2}=$ Pemberian postes

$\mathrm{G}=$ Perlakuan dengan model pembelajaran generatif

$\mathrm{K}=$ Perlakuan dengan model pembelajaran langsung

Untuk menguji hipotesis penelitian digunakan uji t seperti di bawah ini : $\mathrm{t}_{\text {hitung }}=$

(Sudjana, 2005: 239)

Kriteria pengujian terima Ho jika $\mathrm{t}_{\text {hitung }}<\mathrm{t}_{\text {tabel }}$ dimana $\mathrm{t}_{1-\text { didapat dari distribusi } \mathrm{t}}$ dengan $\mathrm{dk}=\mathrm{n}_{1}+\mathrm{n}_{2}-2$ dan peluang (1-). Untuk harga-harga $t$ lainnya $\mathrm{H}_{\mathrm{o}}$ ditolak.

\section{HASIL PENELITIAN DAN PEMBAHASAN \\ Hasil Penelitian}

Penelitian ini merupakan penelitian eksperimen yang melibatkan dua kelas yang diberi model pembelajaran yang berbeda, yaitu model pembelajaran generatif untuk kelas eksperimen, dan pembelajaran dengan model pembelajaran langsung untuk kelas kontrol. Diperoleh rata-rata data pretes kelas eksperimen adalah 34,22 dengan standar deviasi 12,47 dan nilai rata-rata pretes kelas kontrol adalah 35,78 dengan standar deviasi 14,16.
Setelah diberikan perlakuan yang berbeda, kelas eksperimen dengan model pembelajaran generatif dan kelas kontrol dengan model pembelajaran langsung diperoleh rata-rata data postes kelas eksperimen 70.44 dengan standar deviasi 17,65 dan kelas kontrol 60,44 dengan standar deviasi 19,80.

Dari hasil pengamatan yang dilakukan oleh observer diperoleh bahwa aktivitas siswa di kelas eksperimen mengalami peningkatan yang positif. Pada pertemuan I rata-rata aktivitas siswa diperoleh sebesar 58,22. Hal ini dikarenakan siswa belum mengerti instruksi yang diberikan oleh guru. Oleh karena itu, peneliti terus memberikan bimbingan agar siswa selalu aktif dalam kelompoknya. Pada pertemuan II diperoleh peningkatan yang positif terhadap aktivitas siswa dengan nilai rata-rata 68,00. Pada pertemuan ke III diperoleh peningkatan dengan nilai rata-rata 71,56 yang tergolong aktif. Hal ini dikarenakan siswa sudah mulai memahami apa yang harus dikerjakan sehingga keaktifan siswa meningkat.

Pengujian hipotesis data hasil penelitian dilakukan dengan menggunakan uji $\mathrm{t}$ dua pihak dan satu pihak untuk mengetahui apakah hasil belajar siswa dengan menggunakan model pembelajaran generatif tidak sama dengan model pembelajaran langsung pada materi hukum Newton.

Hasil pengujian hipotesis dua pihak diproleh harga $t_{\text {hitung }}<t_{\text {tabel }}$ yaitu $-0,46<$ 1,84 dan hasil pengujian hipotesis satu pihak diperoleh harga $t_{\text {hitung }}>t_{\text {tabel }}$ yaitu 2,06 $>1,84$ pada taraf signifikansi $\alpha=0,05$. Hal ini berarti hipotesis menyatakan ada perbedaan akibat pengaruh model pembelajaran generatif terhadap hasil belajar siswa di kelas VIII semester I SMP yayasan Perguruan Budi Agung Medan Marelan pada materi pokok hukum Newton.

\section{Pembahasan}

Terdapat perbedaan akibat pengaruh model pembelajaran generatif terhadap hasil belajar siswa pada materi hukum 
Newton. Hal ini disebabkan beberapa faktor, diantaranya siswa menjadi aktif dalam belajar karena dilibatkan dalam pembelajaran di setiap fase pembelajaran generatif. Melalui keterlibatan aktif dalam proses pembelajaran, siswa dapat membangun sendiri pengetahuan mereka sehingga pengetahuan yang diperoleh menjadi pengetahuan yang bermakna sehingga hasil belajar yang diperoleh maksimal.

Selama pelaksanaan diperoleh bahwa pembelajaran dengan menggunakan model pembelajaran generatif lebih memberikan kesempatan kepada siswa untuk mengungkapkan pikiran atau pendapat terhadap konsep fisika, serta memberikan contoh nyata kepada siswa, karena siswa dapat menggali sendiri kemampuannya. Dengan kata lain, saat proses pembelajaran siswa dapat mengintegrasikan secara aktif pengetahuan baru dengan menggunakan pengetahuan yang sudah dimiliki siswa sebelumnya. Hal ini terlihat dari setiap fase-fase pada model pembelajaran generatif. Pada fase pendahuluan siswa diberikan motivasi untuk membangkitkan semangat dan keberanian siswa dalam mengawali pembelajaran. Kemudian siswa diberi kwsempatan untuk mengungkapkan pengetahuan, ide, atau konsepsi awal yang diperoleh dari pembelajaran sebelumnya mengenai konsep hukum Newton yang dapat dituliskan di kertas. Pengetahuan awal tersebut akan diintegrasikan dengan pengetahuan baru siswa pada tahap pemfokusan.

Pada tahap pemfokusan siswa diarahkan untuk mengkonstruksi konsep hukum Newton melalui percobaan yang ada di LKS. Setiap siswa mempunyai tugasnya masing-masing melalui percobaan. Pada tahap ini juga terjadi proses mengkonstruksi, diskusi dan Tanya jawab antar siswa. Pertanyaan-pertanyaan yang diberikan melalui LKS juga membuat siswa mencari sendiri jawabannya secara nyata dan lebih aktif, bukan hanya dari membaca buku pedoman saja.
Sebagaimana yang telah dijelaskan bahwa model pembelajaran generatif lebih menekankan pada upaya untuk mengaktifkan siswa membangun pengetahuannya. Dengan pencapaian hasil belajar seperti yang dikemukakan dalam hasil penelitian di atas, dapat dikatakan bahwa hasil tersebut menggambarkan bahwa intisari pembelajaran generatif yakni siswa tidak menerima informasi dengan pasif, tetapi justru dengan aktif mengkonstruksi suatu pengetahuan dari informasi dan kemudian membuat kesimpulan serta mengaplikasikannnya.

Dari proses pembelajaran generatif yang dilaksanakan di kelas eksperimen, persentase aktivitas siswa rata-rata 71,56. Ini menunjukan aktivitas siswa yang tergolong aktif. Hal ini disebabkan karena setiap fase pelaksanan model pembelajaran generatif menuntut siswa untuk lebih aktif menkonstruksi pengetahuan yang dimilikinya melalui aktivitas di setiap fase tersebut. Karena dengan aktivitas siswa dalam proses pembelajaran akan menyebabkan interaksi yang baik antara guru dengan siswa ataupun dengan siswa itu sendiri. Hal ini akan mengakibatkan suasana kelas menjadi menarik dan kondusif, dimana masing - masing siswa dapat melibatkan kemampuannya semaksimal mungkin.

Pembelajaran dengan model pembelajaran generatif membuat interaksi guru dan siswa lebih kondusif, karena dalam pembelajaran yang dilaksanakan, selain bertindak sebagai fasilitator dan motivator, juga bertindak sebagai penghubung pengetahuan yang dimiliki oleh siswa dengan informasi baru yang diterima melalui pertanyaan-pertanyaan diskusi yang sifatnya mengarahkan, terutama akan terjadi pada tahap persiapan, tahap memfokuskan dan tahap tantangan pada proses pembelajaran.

Dari segi pelaksanaan fase-fase model pembelajaran generatif terdapat beberapa kendala yang dihadapi, yaitu pada diskusi kelompok di fase tantangan, terdapat beberapa orang siswa yang kurang 
aktif dalam kelompoknya dan mengganggu kelompok lain. Oleh sebab itu, upaya yang dilakukan adalah lebih memperhatikan dan membimbing siswa selama bekerja dalam kelompok dengan cara aktif bertanya kepada tiap siswa tentang apa yang telah dikerjakannya dalam kelompok dengan begitu siswa akan lebih termotivasi untuk aktif dalam menyelesaikan tugas kelompok. Selain itu, terdapat beberapa orang siswa kurang mengerti dan paham terhadap instruksi atau arahan pelaksanaan pembelajaran dengan model pembelajaran generatif. Untuk mengatasi hal ini, sebaiknya sebelum memulai proses pembelajaran terlebih dahulu dijelaskan kepada siswa pembagian kelompoknya, sehingga pada saat pelaksanaan pembelajaran para siswa sudah mengerti apa yang akan dilakukan dan tidak menyita waktu untuk fase-fase pembelajaran yang lain.

\section{KESIMPULAN DAN SARAN Kesimpulan}

Berdasarkan hasil penelitian dan pembahasan maka dapat disimpulkan bahwa:

1. Rata-rata hasil belajar siswa kelas VIII SMP Yayasan Perguruan Budi Agung Medan Marelan sebelum diberi perlakuan sebesar 34,22 setelah diajarkan menggunakan model pembelajaran generatif menjadi 70,44 .
2. Rata-rata hasil belajar siswa kelas VIII SMP Yayasan Perguruan Budi Agung Medan Marelan sebelum diberi perlakuan sebesar 35,78 setelah diajarkan menggunakan pembelajaran konvensional menjadi 60,44.

3. Berdasarkan hasil perhitungan uji $\mathrm{t}$ diperoleh bahwa

$>(2,06>1,84)$ maka $_{H a}$ di terima yang berarti terdapat perbedaan akibat pengaruh model pembelajaran generatif terhadap hasil belajar siswa pada materi pokok Hukum Newton di kelas VIII semester I SMP Yayasan Perguruan Budi Agung Medan Marelan T.P. 2013/2014.

\section{Saran}

Bagi peneliti selanjutnya diharapkan lebih memperhatikan dan membimbing siswa selama bekerja dalam kelompok dengan cara aktif bertanya kepada tiap siswa tentang apa yang telah dikerjakannya dalam kelompok dengan begitu siswa akan lebih termotivasi untuk aktif dalam menyelesaikan tugas kelompok. Kemudian ada baiknya, sebelum memulai proses pembelajaran terlebih dahulu dijelaskan kepada siswa pembagian kelompoknya, sehingga pada saat pelaksanaan pembelajaran para siswa sudah mengerti apa yang akan dilakukan dan tidak menyita waktu untuk fase-fase pembelajaran yang lain karena terdapat beberapa orang siswa kurang mengerti dan paham terhadap instruksi atau arahan pelaksanaan pembelajaran dengan model pembelajaran generatif.

DAFTAR PUSTAKA

Arikunto, S., 2012, Dasar-dasar Evaluasi Pendidikan, Jakarta, Bumi Aksara

Holil, A., (2008), Model Pembelajaran Generatif. http://anwarholil.blogspot.com/2008/ $\underline{\text { 04/Pembelajaran-generatif- }}$ 
mpg.htm/27/2, diakses pada tanggal 27 februari 2013.

Sa'adah, S., 2009, Penerapan Model Pembelajaran Generatif Untuk Meningkatkan Hasil Belajar Fisika Siswa Smp Setia Bhakti Cilawu
Garut, Skripsi tidak diterbitkan, Bandung, FMIPA UPI

Slameto, 2010, Belajar dan Faktor-Faktor yang Mempengaruhi, Jakarta, Rineka Cipta

Sudjana, 2005, Metoda Statistika, Bandung, Tarsito 